\title{
Effect of Female Weight on Reproductive Potential of the Predator Brontocoris tabidus (Signoret, 1852) (Heteroptera: Pentatomidae)
}

\author{
Isaias Oliveira ${ }^{1}$, José Cola Zanuncio ${ }^{1}$, José Eduardo Serrão ${ }^{1,2^{*}}$, Teresinha Vinha Zanuncio ${ }^{1}$, \\ Tobias Baruc Moreira Pinon ${ }^{1}$ and Maria do Carmo Queiroz Fialho ${ }^{1}$ \\ ${ }^{1}$ Departamento de Biologia Animal; ${ }^{2}$ Departamento de Biologia Geral; Universidade Federal de Viçosa; 36571-000; \\ Viçosa - MG - Brazil
}

\begin{abstract}
The objective of this work was to determine the fecundity of the predator Brontocoris tabidus (Signoret) (Heteroptera: Pentatomidae) females of two weight classes aiming to define, which one presented higher productivity in the laboratory. Males and females of $\mathrm{B}$. tabidus were reared from nymphs fed with Tenebrio molitor L. (Coleoptera: Tenebrionidae) pupae in laboratory. Females of B. tabidus weighting 95 to 150 mg and those with 160 to $220 \mathrm{mg}$ constituted two treatments. Oviposition period and numbers of egg masses, eggs and nymphs per female of $\mathrm{B}$. tabidus were higher in the treatment with heavier females, while the periods of preoviposition, between egg mass laying, egg incubation and number of eggs per egg mass, besides the percentage of nymphs hatched and adult longevity were similar between treatments. Heavier females of B. tabidus presented better productivity and for this reason they should be used in programs of mass rearing this predator.
\end{abstract}

Key words: Asopinae, predatory bugs, mass rearing, biological control, reproductive potential

\section{INTRODUCTION}

Generalist predators are important for biological control of pests because they can feed on many insect species, especially those that are present in high numbers. In addition, these natural enemies show colonization potential in different agroecosystems, even in periods of prey shortage (De Clercq and Degheele, 1990, Zanuncio et al., 2001). Nymphs and adults of Brontocoris tabidus (Signoret) (Heteroptera: Pentatomidae) prey on all stage insects of many orders (Barcelos et al., 1994). Podisus nigrispinus (Dallas) (Heteroptera: Pentatomidae) and B. tabidus are the most common and frequent predators in eucalyptus plantations, while Alcaeorrhynchus grandis (Dallas), Tynacantha marginata Dallas, Oplomus sp. and Supputius cincticeps (Stal) are less frequent. For this reason, the first two species have been reared and released for biological control in agricultural and forest agroecosystems (Zanuncio et al., 1994, Zanuncio et al., 1996/1997a). B. tabidus and $P$. nigrispinus present good adaptation to laboratory conditions where they have higher productivity and short biological cycle. They are considered promising species for pest management programs in Brazil (Saavedra et al. 1997; Lemos et al. 2001).

Biological aspects of natural enemies vary with biotic and abiotic factors, which can affect their

\footnotetext{
*Author for correspondence
} 
use in biological control programs (Saavedra et al., 1997; Zanuncio et al., 1996; Zanuncio et al., 2000; Torres and Zanuncio, 2001). Geographic origin affects the body size of $P$. nigrispinus, but no significant relationship between body size and fecundity was found for strains of $P$. nigrispinus from Surinam and Brazil, except in the first generation in laboratory (Mohaghegh et al., 1999). This suggested that higher fecundity and longevity of these predators could reflect its adaptation to the diet and to laboratory conditions. Other authors found that fecundity of predatory Pentatomidae varied with female body weight, with heavier females presenting better reproductive rate (Honek, 1993; Evans, 1982a, b; Zanuncio et al., 1992).

Positive correlation between female weight and fecundity of many insects and weight variation in the same population of $B$. tabidus suggest the need to study the effect of this factor on reproductive capacity of this predator. Hence, we studied the effect of female body weight on the reproduction of $B$. tabidus fed with $T$. molitor pupae, in order to improve fecundity of this species in mass rearing facilities.

\section{MATERIALS AND METHODS}

Adults of B. tabidus were obtained from nymphs fed with $T$. molitor pupae and seedlings of Eucalyptus urophylla maintained at $25 \pm 2{ }^{\circ} \mathrm{C}, 65$ $\pm 10 \% \mathrm{RH}$ and $13 \mathrm{~h}$ photophase (Moreira et al., 1996/1997). Twenty-four hours after emergence, starved adults of B. tabidus were divided in two groups according to their body size. Group I $\left(\mathrm{T}_{1}\right)$ included females with body weight from 95 to 150 $\mathrm{mg}$, while group II $\left(\mathrm{T}_{2}\right)$ had females with body weight from 160 to $220 \mathrm{mg}$. In both groups, male weight varied from 72 to $147 \mathrm{mg}$. These weight classes were used based upon the $45 \%$ of heavier and $45 \%$ lighter females in the B. tabidus population available in the laboratory.

Thirty pairs of B. tabidus were isolated in 30 plastic containers (2 1) with one pair/container. The cover of these plastic containers had a hollow where a plastic cup $(40 \mathrm{ml})$ with the bottom substituted by a nylon mesh was inserted in which five T. molitor pupae/day were supplied. A plastic cup $(500 \mathrm{ml})$ with a seedling of E. urophylla, changed every four days substituted the bottom of the plastic containers. Water was supplied in cylindrical tubes $(2 \mathrm{ml})$ fixed to the containers wall (Assis-Júnior et al., 1998). These containers were daily observed and egg masses of B. tabidus were collected and transferred to Petri dishes $(9.0 \times 1.2 \mathrm{~cm})$ with a moist cotton ball (Barcelos et al., 1993).

The following biological parameters were evaluated: preoviposition, oviposition and postoviposition periods, period between laying (rate between oviposition period and number of egg masses), number of egg masses, number of eggs per egg mass, number of nymphs per egg mass, number of nymphs, percentage of nymphs hatched, egg incubation period, egg viability and female longevity.

Dataset was submitted to Cochran and Bartlett and Lilliefors statistical tests to determine the variance homogeneity and normality, respectively. Data of the period between egg mass laying, number of eggs and eggs/egg mass were transformed in $V_{x}$ and the period of egg incubation in $\log \mathrm{x}$. All data were submitted to the $\mathrm{F}$ test at $5 \%$ significance level.

\section{RESULTS}

Periods of preoviposition and between eggs mass laying were similar in groups $\mathrm{T}_{1}$ and $\mathrm{T}_{2}(\mathrm{~F}, \mathrm{p} \geq$ 0.05 ), while oviposition period and number of egg masses were higher for heavier females $(\mathrm{F}, \mathrm{p}<$ 0.01) (Table 1). Heavier females presented higher number of eggs and nymphs $(\mathrm{F}, \mathrm{p}<0.01)$, but the number of eggs/egg mass, percentage of nymphs hatched, post-oviposition period and female longevity were similar between $\mathrm{T}_{1}$ and $\mathrm{T}_{2}(\mathrm{~F}, \mathrm{p} \geq$ 0.05) (Table 1).

Survival was higher for heavier females of $B$. tabidus, with about $50 \%$ of them alive when they were 35 and 45 days old, for lighter and heavier ones, respectively (Fig. 1). Heavier females showed higher daily and accumulated number of eggs and nymphs/female (daily average number of eggs and nymphs/female for each five days) besides longer survival (percentage of alive females every five days) than lighter ones (Figs. 2, 3).

Lighter females of B. tabidus showed higher egg production when they were about 15 days old, with oscillation between 25 and 35 days and decrease from 40 days older (Fig. 2). The beginning of the period with higher egg production for heavier females was close to their 15 days of 
age, with low oscillation up to 30 days and accentuated decreasing when they were older than 45 days (Fig. 2). Nymph hatching began after 20 days for lighter females, with oscillations to about
30 days and constant decrease from 46 days, while nymph hatching for heavier females began after 15 days and extended up to 60 days (Fig. 3).

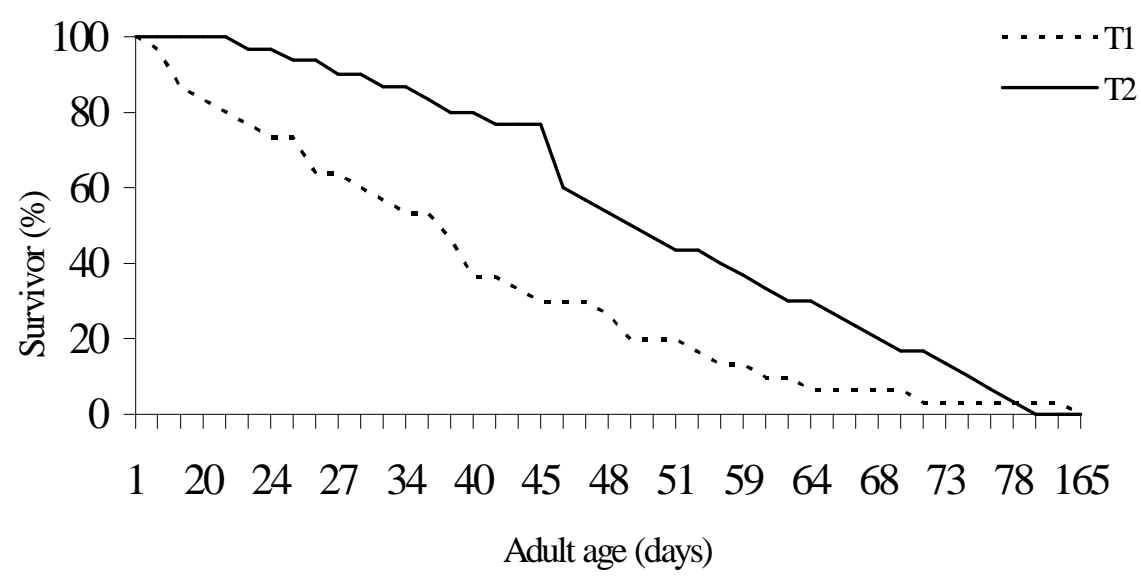

Figure 1 - Survival (\%) of Brontocoris tabidus (Heteroptera: Pentatomidae) females with weight between 95 and $150 \mathrm{mg}\left(\mathrm{T}_{1}\right)$ and between 160 and $220 \mathrm{mg}\left(\mathrm{T}_{2}\right) .25 \pm 2{ }^{\circ} \mathrm{C}, 60 \pm 5 \%$ $\mathrm{RH}$ and $13 \mathrm{~h}$ photophase.

Table 1 - Biological parameters (mean \pm sd) of Brontocoris tabidus (Heteroptera: Pentatomidae) females with weight between 95 and $150 \mathrm{mg}\left(\mathrm{T}_{1}\right)$ and between 160 and $220 \mathrm{mg}\left(\mathrm{T}_{2}\right) .25 \pm 2{ }^{\circ} \mathrm{C}, 60 \pm 5 \% \mathrm{RH}$ and $13 \mathrm{~h}$ photophase.

\begin{tabular}{lccc}
\hline \multicolumn{1}{c}{ Biological parameters evaluated } & $\mathbf{T}_{\mathbf{1}}$ & $\mathbf{T}_{\mathbf{2}}$ \\
\hline Preoviposition period (days) & $16.53 \pm 3.33$ & $16.09 \pm 2.57$ \\
Oviposition period (days)** & $9.5 \pm 2.90$ & $23.03 \pm 3.27$ \\
Number of egg masses/female* & $0.90 \pm 0.20$ & $3.56 \pm 0.57$ \\
Period between laying (days) & $9.29 \pm 2.61$ & $5.62 \pm 0.79$ \\
Number of eggs/female** & $45.33 \pm 11.09$ & $182.89 \pm 33.82$ \\
Number of eggs/egg mass & $47.05 \pm 6.87$ & $51.48 \pm 3.05$ \\
Egg incubation period (days) & $5.52 \pm 0.93$ & $6.87 \pm 0.25$ \\
Porcentage of nymph hatching (\%) & $56.32 \pm 10.68$ & $52.50 \pm 6.15$ \\
Number of nymphs/egg mass** & $32.47 \pm 9.82$ & $101.56 \pm 23.26$ \\
Post-oviposition period (days) & $13.05 \pm 3.59$ & $16.33 \pm 1.71$ \\
Longevity (days) & $40.76 \pm 5.31$ & $52.89 \pm 3.64$ \\
\hline
\end{tabular}

* significant at $5 \%$ probability for the $\mathrm{F}$ test. ** significant at $1 \%$ probability for the $\mathrm{F}$ test.

\section{DISCUSSION}

Positive correlation between body size and fecundity has been found for various insect species (Evans, 1982b). However, weight of these organisms can be influenced by genetic and nongenetic factors, such as environmental conditions (Honek, 1993). Similar results were observed for Pentatomidae predators, with non genetic factors affecting the weight of these insects including qualitative and quantitative effects of food type, temperature, geographical origin, physical environmental conditions, frequency and mating age (Zanuncio et al., 1992; Molina- Rugama et al., 1998; Torres et al., 1998; Mohaghegh et al., 1999; Torres and Zanuncio, 2001). Evans (1982a) stated that differences in body weight of field collected adult predators were mainly due to predatory efficiency of the nymphs that arisen them. Heavier females of $B$. tabidus produced higher number of 
eggs and nymphs which agreed with Evans (1982b), who found significant differences in the total egg production among females of different weight classes, with increasing egg production beginning at the $10^{\text {th }}$ day after emergence of Podisus maculiventris Say (Heteroptera: Pentatomidae) adults. Higher reproductive capacity of B. tabidus, also, agreed with results of Zanuncio et al. (1992) that found higher productivity of heavier females of $P$. nigrispinus fed with Musca domestica L. (Diptera: Muscidae). Reproductive rate of $B$. tabidus females was about half of that described by Barcelos et al. (1994), because heavier females of this predator (179.9 $\mathrm{mg}$ ) produced 182.89 eggs, while the lightest ones
(135.58 $\mathrm{mg}$ ) produced 45.33 eggs. In addition, we found longer preoviposition period for both body weight groups (16.53 and 16.09 days) when compared with results of Barcelos et al. (1994). This can be due to the prey type because these authors used Bombyx mori L. (Lepidoptera: Bombycidae) caterpillars, which can be a more appropriate prey for this predator. Food quality has been one of the main factors affecting weight, size and reproductive capacity of predators (Evans, 1982b; De Clercq and Degheele, 1992; Legaspi and O'Neil, 1994; Zanuncio et al., 1996/1997b), because well fed nymphs arisen heavier adults with higher reproductive capacity (MolinaRugama et al., 1997).
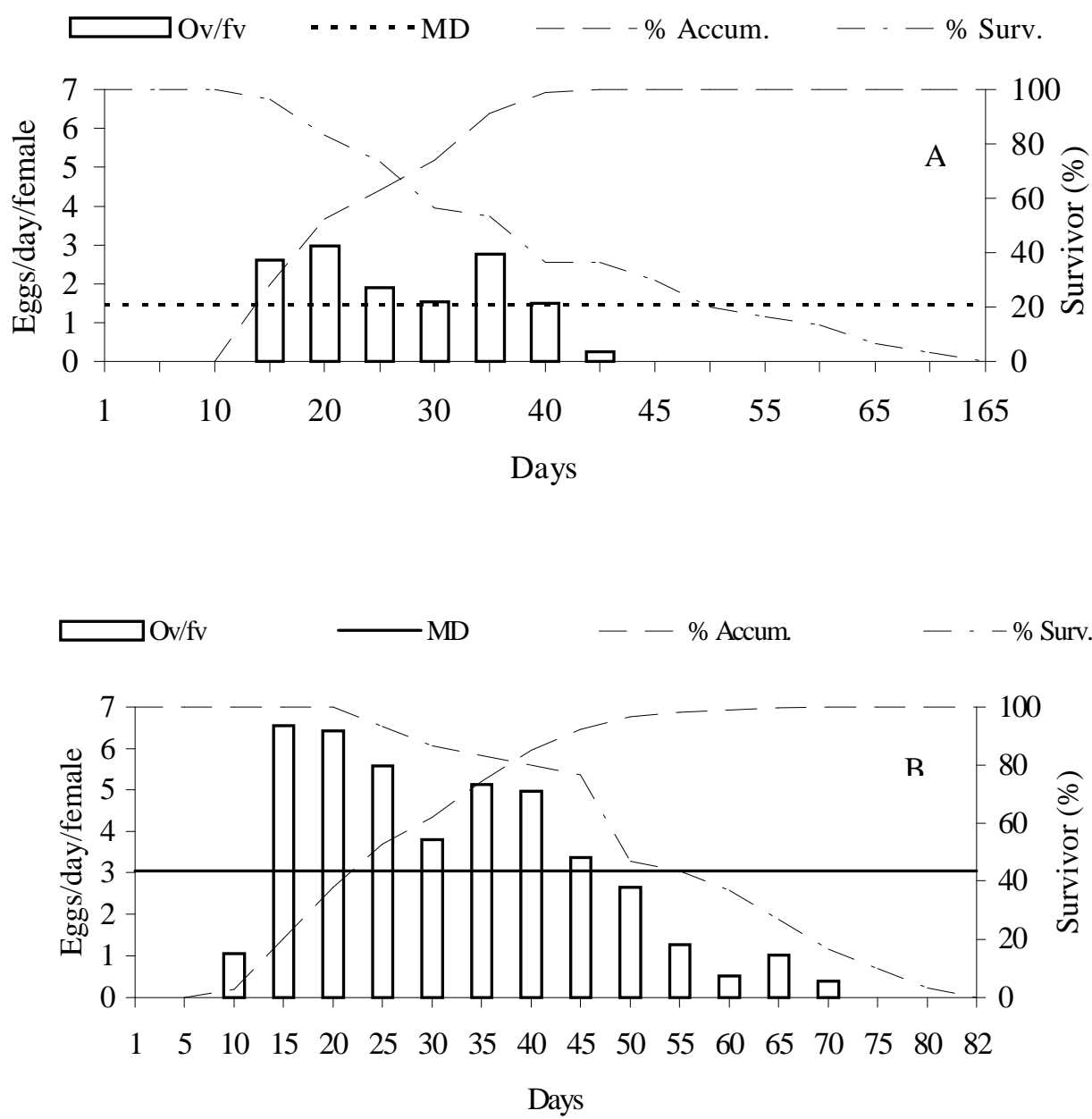

Figure 2 - Daily (ov/f), mean number of eggs/day (MD), accumulated rate of eggs/female every five days (\% Accum) and survival every five days (\% Surv.) of Brontocoris tabidus (Heteroptera: Pentatomidae) females with weight between 95 and $150 \mathrm{mg}(\mathrm{A})$ and between 160 and $220 \mathrm{mg}$ (B). $25 \pm 2^{\circ} \mathrm{C}, 60 \pm 5 \% \mathrm{RH}$ and $13 \mathrm{~h}$ photophase. 

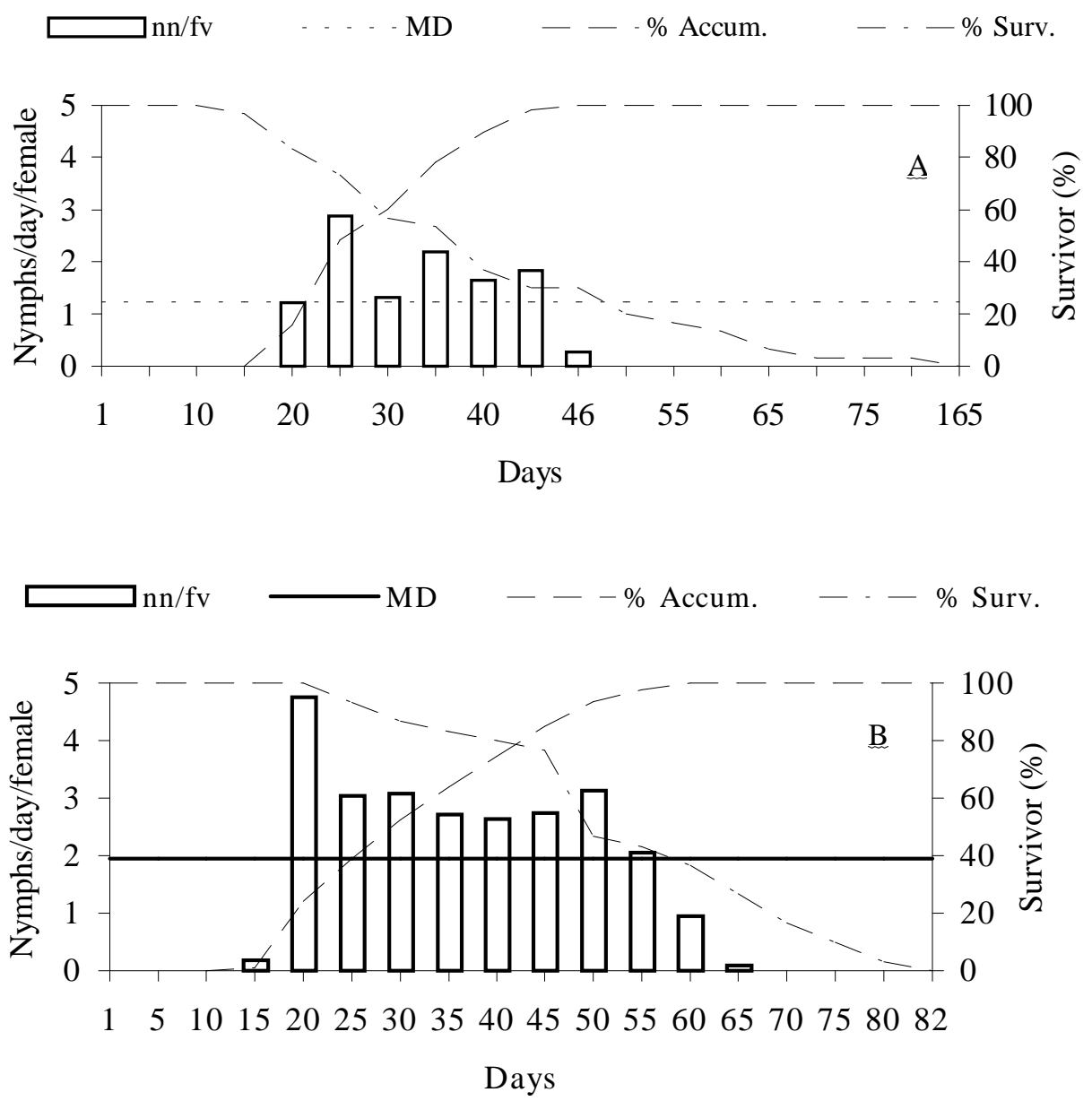

Figure 3 - Daily (nn/f), mean number of nymphs/day (MD), accumulated rate of nymphs/female every five days (\% Accum.) and survival every five days (\% Surv.) of Brontocoris tabidus (Heteroptera: Pentatomidae) females with weight between 95 and $150 \mathrm{mg}$ (A) and between 160 and $220 \mathrm{mg}(\mathrm{B}) .25 \pm 2{ }^{\circ} \mathrm{C}, 60 \pm 5 \% \mathrm{RH}$ and $13 \mathrm{~h}$ photophase.

Prey type and biological parameters of parental generation affect body weight of $B$. tabidus, because nymphs of this predator, fed with fresh $B$. mori caterpillars arisen heavier females $(170 \mathrm{mg})$ than those fed with previously frozen caterpillars of this Lepidoptera species (Barcelos et al., 1991). Heavier B. tabidus females $\left(\mathrm{T}_{2}\right)$ had higher fecundity what can be related to their longer oviposition period and higher number of egg masses.

B. tabidus females of both weight classes showed similar longevity what could be explained by the fact that females of both groups might use similar amount of energy for their survival. Since lighter females should have lower amount of stored energy, they laid fewer eggs. In addition, these females could present longer periods between egg mass laying and fewer numbers of egg masses and/or shorter oviposition periods. Barcelos et al. (1994) found that heavier females of B. tabidus fed on $B$. mori caterpillars produced higher number of eggs, egg masses and nymphs, besides having longer oviposition period and longevity, in a similar way of results herein presented for females of this predator fed on T. molitor larvae, suggesting that these biological parameters were not affected by prey type supplied to this predator. Reproductive rate was higher from the $10^{\text {th }}$ to $45^{\text {th }}$ days after emergence for heavier females, suggesting that $B$. tabidus females should be discarded after this period, in mass rearing programs, when the number of nymphs/female was lower than the average, which could decrease production of this predator. This agreed with 
Rabinovich (1978) that pointed out that non-social insects usually presented an early period without reproduction followed by the reproductive phase and with a decrease after this period.

Heavier females of $B$. tabidus produced higher offspring number and for this reason they should be used for mass rearing this predator.

\section{ACKNOWLEDGEMENTS}

We thank to the Brazilian research agencies "Conselho Nacional de Desenvolvimento Científico e Tecnológico (CNPq)", "Coordenação de Aperfeiçoamento de Pessoal de Nível Superior (CAPES)" and "Fundação de Amparo à Pesquisa do Estado de Minas Gerais (FAPEMIG)" for grants.

\section{RESUMO}

Este trabalho apresenta a fecundidade de fêmeas do predador Brontocoris tabidus (Signoret) (Heteroptera: Pentatomidae) de duas classes de peso, objetivando avaliar qual delas apresenta melhor produtividade em criações mantidas em laboratório. Machos e fêmeas foram alimentadas, desde o estádio ninfal, com pupas do besouro Tenebrio molitor L. (Coleoptera: Tenebrionidae). Fêmeas de B. tabidus pesando entre 95 e $150 \mathrm{mg}$ e entre 160 e $220 \mathrm{mg}$ constituíram as duas classes de peso. O período de oviposição e os números de posturas, de ovos e ninfas por fêmea de B. tabidus foram maiores naquelas fêmeas pertencentes à classe mais pesada, enquanto os períodos de préoviposição, entre posturas, incubação dos ovos e número de ovos por postura, bem como a percentagem de eclosão de ninfas e a longevidade dos adultos foram semelhantes entre ambas as classes de peso. Fêmeas mais pesadas de $B$. tabidus apresentaram maior número de ovos por fêmea e por esta razão devem ser utilizadas em programas de criação massal deste predador.

\section{REFERENCES}

Assis-Junior, S. L.; Zanuncio, T. V.; Santos, G. P. and Zanuncio, J. C. (1998), Efeito da suplementação de folhas de Eucalyptus urophylla no desenvolvimento e reprodução do predador Supputius cincticeps (Stal)
(Heteroptera: Pentatomidae). An. Soc. Entomol. Brasil, 27, 245-253.

Barcelos, J. A. V.; Zanuncio, J. C.; Santos, G. P. and Reis, F. P. (1991), Viabilidade da criação em laboratório de Podisus nigrolimbatus (Spinola, 1852) (Hemiptera, Pentatomidae) sobre duas dietas. Rev. Árv., 15, 316-322.

Barcelos, J. A. V.; Zanuncio, J. C.; Nascimento, E. C. and Zanuncio, T. V. (1993), Caracterização dos estádios ninfais de Podisus nigrolimbatus (Spinola, 1852) (Hemiptera, Pentatomidae). Rev. Bras. Entomol., 37, 537-543.

Barcelos, J. A. V.; Zanuncio, J. C.; Oliveira, A. C. and Nascimento, E. P. (1994), Performance em duas dietas e descrição dos adultos de Brontocoris tabidus (Signoret) (Heteroptera: Pentatomidae). An. Soc. Entomol. Brasil, 23, 519-524.

De Clercq, P. and Degheele, D. (1990), Description and life history of the predatory bug Podisus sagitta (Fab.) (Heteroptera: Pentatomidae). Can. Entomol., 122,1149-1156.

De Clercq, P. and Degheele, D. (1992), Influence of feeding interval on reproduction and longevity of Podisus sagitta (Heteroptera: Pentatomidae). Entomophaga, 37, 583-590.

Evans, E. W. (1982a), Timing of reproduction by predatory stinkbugs (Hemiptera: Pentatomidae): patterns and consequences for a generalist and a specialist. Ecology, 63, 147-158.

Evans, E. W. (1982b), Consequences of body size for fecundity in the predatory stinkbug, Podisus maculiventris (Hemiptera: Pentatomidae). Ann. Entomol. Soc. Am., 75, 418-420.

Honek, A. (1993), Intraspecific variation in body size and fecundity in insects: a general relationship. Oikos, 66, 483-492.

Legaspi, J. C. and O'Neil, R.J. (1994), Developmental response of nymphs of Podisus maculiventris (Heteroptera: Pentatomidae) reared with low numbers of prey. Environ. Entomol., 23, 374-380.

Lemos, W. P.; Medeiros, R. S.; Ramalho, F. S. and Zanuncio, J. C. (2001), Effects of plant feeding on the development, survival and reproduction of Podisus nigrispinus (Dallas) (Heteroptera: Pentatomidae). Int. J. Pest Manage., 47, 89-93.

Mohaghegh, J.; De Clercq, P. and Tirry, L. (1999), Effects of rearing history and geographical origin on reproduction and body size of the predator Podisus nigrispinus (Heteroptera: Pentatomidae). Eur. J. Entomol., 96, 69-72.

Molina-Rugama, A. J.; Zanuncio, J. C.; Torres, J. B. and Zanuncio, T. V. (1997), Longevidad y fecundidad de Podisus nigrispinus (Heteroptera: Pentatomidae) alimentado con Musca domestica (Diptera: Muscidae) y frijol. Rev. Biol. Trop., 45, 1125-1130. 
Molina-Rugama, A. J.; Zanuncio, J. C.; Zanuncio, T. V. and Oliveira M. L. R. (1998), Reproductive strategy of Podisus rostralis (Stal) (Heteroptera: Pentatomidae) females under different feeding intervals. Bioc. Sci. Tech., 8, 583-588.

Moreira, L. A.; Zanuncio, J. C.; Picanço, M. C. and Guedes, R. N. C. (1996/1997), Effect of Eucalyptus feeding in the development, survival and reproduction of Tynacantha marginata (Heteroptera: Pentatomidae). Rev. Biol. Trop., 44/45, 253-257.

Rabinovich, J. E. (1978), Ecologia de poblaciones animales. Washington : Secretaria General de la Organización de los Estados Americanos.

Saavedra, J. L. D.; Zanuncio, J. C.; Zanuncio, T. V. and Guedes, R. N. C. (1997), Prey capture ability of Podisus nigrispinus (Dallas) (Heteroptera: Pentatomidae) reared for successive generations on meridic diets. J. Appl. Entomol., 121, 327-330.

Torres, J. B. and Zanuncio, J. C. (2001), Effect of mating frequency of Podisus nigrispinus on female reproductive output. BioControl, 46, 469-480.

Torres, J. B.; Zanuncio, J. C. and Oliveira, H. N. (1998), Nymphal development and adult reproduction of the stinkbug predator Podisus nigrispinus (Heteroptera: Pentatomidae) under fluctuating temperatures. J. Appl. Entomol., 122, 509-514.

Zanuncio, J. C.; Bragança, M. A. L.; Díaz, J. L. S. and Sartório, R. C. (1992), Avaliação dos parâmetros de fecundidade de fêmeas de Podisus connexivus (Hemiptera: Pentatomidae) de diferentes pesos. Rev. Ceres, 39, 591-596.

Zanuncio, J. C.; Alves, J. B.; Zanuncio, T. V. and Garcia, J. F. (1994), Hemipterous predators of eucalypt defoliator caterpillars. For. Ecol. Manag., 65, 65-73.

Zanuncio, J. C.; Saavedra, J. L. D; Zanuncio, T. V. and Santos, G. P. (1996/1997a), Desarollo y reproducción de Supputius cincticeps (Heteroptera: Pentatomidae) en dieta artificial por dos generaciones. Rev. Biol. Trop., 44/45, 247-251.
Zanuncio, J. C.; Saavedra, J. L. D., Zanuncio, T. V. and Santos, G. P. (1996/1997b), Incremento en el peso de ninfas y adultos de Podisus nigrispinus (Heteroptera: Pentatomidae) alimentados com dos tipos de larvas. Rev. Biol. Trop., 44/45, 241-245.

Zanuncio, J. C.; Zanuncio, T.V.; Guedes, R.N.C. and Ramalho, F.S. (2000), Effect of feeding on three Eucalyptus species in the development of Brontocoris tabidus (Het.: Pentatomidae) fed with Tenebrio molitor (Col.: Tenebrionidae). Bioc. Sci. Tech., 10, 443-450.

Zanuncio. J. C.; Molina-Rugama, A. J.; Serrão, J. E. and Pratissoli, D. (2001), Nymphal development and reproduction of Podisus nigrispinus (Heteroptera: Pentatomidae) fed with combinations of Tenebrio molitor (Coleoptera: Tenebrionidae) pupae and Musca domestica (Diptera: Muscidae) larvae. Bioc. Sci. Tech., 11, 331-337.

Zanuncio, J. C.; Saavedra, J. L. D.; Oliveira, H. N.; Degheele, D. and De Clercq, P. (1996), Development of the predatory stinkbug Brontocoris tabidu(Signoret) (Heteroptera: Pentatomidae) on different proportions of an artificial diet and pupae of Tenebrio molitor L. (Coleoptera: Tenebrionidae). Bioc. Sci. Tech., 6, 619-625.

Received: September 10, 2003; Revised: March 05, 2004; Accepted: July 09, 2004. 